\title{
EFEKTIVITAS PELATIHAN PENERIMAAN DIRI DALAM MENINGKATKAN PENERIMAAN DIRI PSK DI PPSKW MATTIRO DECENG
}

THE EFFECTIVITY OF MODIFIED SELF-ACCEPTANCE EXERCISE TO IMPROVE

SELF-ACCEPTANCE OF COMMERCIAL SEX WORKERS IN PPSKW MATTIRO DECENG Aprilia Islamiyanti Kusumaningrum ${ }^{(1)}$, Eva Meizara Puspita Dewi ${ }^{(2)}$, Muhammad Nur Hidayat Nurdin $^{(3)}$

Program Studi Psikologi, Fakultas Psikologi Universitas Negeri Makassar ${ }^{(1)}$,Program Studi Psikologi, Fakultas Psikologi Universitas Negeri Makassar ${ }^{(2)}$, Program Studi Psikologi, Fakultas Psikologi

$$
\text { Universitas Negeri Makassar (3) }
$$

E-mail: aprildahyo@gmail.com ${ }^{(1)}$,evabasti@yahoo.com ${ }^{(2)}$,dayat20858@gmail.com ${ }^{(3)}$

\begin{abstract}
Abstrak: Penelitian ini bertujuan untuk mengetahui efektivitas pelatihan peneriman diri yang didasari oleh teknik self-compassion dalam meningkatkan penerimaan diri PSK di PPSKW Mattiro Deceng, Makassar. Subjek penelitian berjumlah 4 orang yang memiliki kecenderungan penerimaan diri rendah. Penelitian ini menggunakan desain penelitian kuasi eksperimen the one-group pretest-posttest design with follow-up. Alat ukur dalam penelitian ini menggunakan skala penerimaan diri yang disusun oleh peneliti bersadasarkan aspek-aspek penerimaan diri oleh Sheerer. Data dianalisis dengan cara membandingkan nilai rata-rata setiap tahapan pengukuran pre-test $(M=81,75)$, post-test $(M=98,5)$, follow-up(M=102,5). Hasil penelitian menunjukkan bahwa terdapat peningkatan nilai rata-rata pada setiap tahapan pengukuran, sehingga modifikasi pelatihan penerimaan diri yang diberikan efektif untuk meningkatkan penerimaan diri pada pekerja seks komersial di PPSKW Mattiro Deceng, Makassar. Implikasi dari penelitian ini adalah pelatihan penerimaan diri dapat dijadikan sebagai alternatif metode untuk meningkatkan penerimaan diri bagi individu, khususnya pekerja seks komersial.
\end{abstract}

Kata Kunci: konsep diri ,mindfulness, pekerja seks komersial, penerimaan diri, self-compassion

\begin{abstract}
This study aims to investigate the effectiveness of modified self-acceptance exercise based on self-compassion techniques, to improve self-acceptance of sex workers in PPSKW Mattiro Deceng, Makassar. The participants were a single group of 4 sex-workers ( $M$ age $=44)$ with low selfacceptance tendencies. A quasi-experimental design of one-group pretest-posttest with follow-up has used in this study. The Follow-up was done a week after the treatment was given. The measuring instrument uses a self-acceptance scale based on aspects of self-acceptance by Sheerer. Data of each measuring section were being compared, and shows an improvement of mean scores in each section, pre-test $(M=81,75)$, post-test $(M=98,5)$, follow-up $(M=102,5)$ The results suggest that, the related exercise might effective to improve self-acceptance of sex workers in PPSKW Mattiro Deceng, Makassar. The implication of this study suggest that the exercise can be used as an alternative method to improve self-acceptance for individuals, especially sex workers.
\end{abstract}

Keywords: mindfulness, self-acceptance, self-compassion,self-concept, sex workers.

\section{PENDAHULUAN}

Berbagai program rehabilitasi telah dirancang oleh Pemerintah di berbagai daerah, namun faktanya proses pelaksanaan program masih belum optimal. Hasil wawancara yang telah dilakukan oleh peneliti terhadap pekerja sosial yang bertugas sebagai Kepala Tata Usaha di Pusat Pelayanan Sosial Karya Wanita (PPSKW) Mattiro Deceng mengungkapkan bahwa angka presentasi PSK yang terjaring kembali setelah dibebaskan dari masa rehabilitasi sangat besar, yakni mencapai $75 \%$.
Beberapa PSK bahkan dapat tertangkap kembali dan menjalankan proses rehabilitasi selama tiga atau empat kali berturut-turut.

Pusat Pelayanan Sosial Karya Wanita (PPSKW) Mattiro Deceng sebagai satu-satunya wadah penjaringan dan rehabilitasi PSK di Sulawesi Selatan, mencatat bahwa sejak tahun 2013 hingga 2018 jumlah PSK yang terjaring dan dibina selalu mencapai batas kapasitas maksimum, yakni 100 orang dalam setahun. Jumlah tersebut dapat menjadi beberapa kali lipat lebih besar karena banyak PSK yang 
bekerja di tempat-tempat tersembunyi, ilegal, dan tidak terdata.

Faktor utama yang membentuk perilaku individu untuk melacurkan diri yaitu, kemiskinan dan kepribadian. Pekerjaan sebagai PSK mendapat banyak sikap reaktif dari masyarakat yang cenderung memberikan label negatif terhadap PSK, karena dianggap tidak memiliki moral dan telah melanggar adat istiadat, hukum, serta agama. Label negatif yang dikaitkan pada diri PSK menimbulkan adanya konflik dan kecemasan, sehingga memengaruhi keadaan diri para PSK (Kartono, 2017).

Sahyana (2017) dalam penelitiannya juga menemukan bahwa salah satu faktor yang memengaruhi PSK di PPSKW Mattiro Deceng untuk kembali melakukan tindakan prostitusi adalah pembentukan konsep diri positif yang kurang optimal selama proses rehabilitasi di PPSKW Mattiro Deceng. Hasil evaluasi program yang ditemukan yaitu, materi yang dibawakan kurang menarik dan terus berulang, serta sikap pekerja sosial yang terkesan kurang menghargai PSK

Peneliti melakukan pengambilan data awal melalui wawancara singkat pada tanggal 9 Oktober 2019 kepada 10 orang PSK sebagai penerima manfaat di PPSKW Mattiro Deceng terkait kondisi faktual yang dirasakan dan menemukan bahwa, 8 dari 10 responden mengaku merasa belum bahagia dan tidak puas dengan kondisinya saat ini. Tujuh dari 10 responden mengaku minder dengan individu lain dikarenakan berbagi macam alasan seperti, pekerjaan, kondisi ekonomi, keluarga, hingga tampilan fisik. Tujuh dari 10 responden mengalami penolakan, sehingga memilih sikap untuk menjauhkan diri dari masyarakat akibat label negatif yang diterima. Terkait masa depannya, 10 dari 10 responden mengaku bingung dan belum yakin dengan kemampuannya untuk dapat bahagia di masa depan.

Data yang diperoleh oleh peneliti sejalan dengan penelitian yang dilakukan oleh Angeline dan Ronda (2011) di PPSKW Mattiro Deceng yang mengungkap bahwa PSK menganggap dirinya sebagai individu yang rendah dan tidak bernilai di hadapan Tuhan dan individu lain. Kondisi diri yang mendukung seperti kehidupan ekonomi yang sulit, latar belakang pendidikan rendah, pengalaman traumatis di masa lalu, dan penilaian yang terlanjur buruk membuat para PSK terus menjual diri.

Hasil perolehan data awal responden juga memiliki beberapa kemiripan dengan indikasi karakteristik individu yang memiliki penerimaan diri rendah yang dikemukakan oleh Sari dan Nuryoto (2002), yaitu individu tidak memiliki keyakinan dan kemampuan diri dalam menjalani hidup, menganggap diri kurang berharga sebagai seorang individu yang sederajat dengan individu lain, memiliki anggapan aneh terhadap diri dan ketakutan untuk ditolak oleh individu lain, tidak mengenal diri dengan baik dan merasa malu terhadap keadaan diri, tidak bertanggung jawab terhadap segala perbuatannya, serta tidak menerima pujian dan celaan secara objektif.

Permatasari dan Gamayanti (2016) mengemukakan bahwa penerimaan diri merupakan derajat individu ketika mengetahui karakteristik personalnya dengan baik berupa kelebihan dan kekurangan yang dimiliki. Individu yang sadar terhadap keadaan diri dapat menerima dan termotivasi untuk membentuk integritas pribadi. Sheerer (1949) mengemukakan bahwa aspek penerimaan diri individu meliputi perasaan diri yang sederajat terhadap individu lain, percaya terhadap kemampuan diri dalam menghadapi persoalan kehidupan, bertanggung jawab atas perilakunya, orientasi keluar diri, berpendirian, menyadari keterbatasan diri, dan menerima sifat kemanusiaan.

Berdasarkan data yang diperoleh peneliti melalui wawancara tersebut, menunjukkan bahwa PSK belum mampu memahami dan mengenal diri seutuhnya, sehingga menjalankan peran yang sebenarnya tidak disenangi dan berdampak buruk dalam eksistensinya di keluarga dan masyarakat. Penerimaan diri berguna bagi PSK untuk mengevaluasi diri agar mampu mengenal berbagai kelebihan dan keterbatasan yang dimiliki secara adil dan objektif, sehingga dapat membentuk kesadaran dan harapan untuk menjalani hidup yang lebih realistis.

Penerimaan diri dapat ditingkatkan melalui bermacam intervensi yang dapat dilakukan secara individu maupun kelompok. Beberapa metode yang dapat digunakan berupa latihan penerimaan diri, positive focus group, dan meditasi. Beberapa metode diatas mengajarkan individu untuk lebih mengenal diri dengan meningkatkan self-awareness, menyadari pengalaman dan emosi tanpa penilaian, 
mengembangkan sikap compassion dan pemaafan, serta lebih terhubung dengan individu lain (Ackerman, 2019).

Berdasarkan hal tersebut, peneliti telah merancang sebuah pelatihan penerimaan diri yang berfokus pada sikap self-compassion pada individu. Neff (2003a) mengemukakan bahwa self-compassion merupakan cara individu dalam menyembuhkan diri dengan kebaikan, memahami penderitaan sebagai pengalaman, serta menganggap kelebihan, kekurangan, dan kegagalan sebagai bagian dari kehidupan. Pelatihan penerimaan diri melibatkan modifikasi materi dan beberapa aktivitas yang pada umumnya didasari oleh komponen selfcompassion yang telah dilakukan dari beberapa penelitian sebelumnya. Modifikasi ini bertujuan untuk menyesuaikan materi dengan kebutuhan subjek penelitian.

Self-compassion memiliki beberapa komponen yaitu, self-kindness, common humanity, dan mindfulness. Self-kindness meliputi sikap memaafkan, empati, sensitivitas, kehangatan, dan kesadaran terhadap seluruh aspek diri termasuk semua sikap, perasaan, pikiran, dan dorongan. Common humanity meliputi pemaafan terhadap diri karena telah menjadi manusia seutuhnya, yaitu dengan memiliki keterbatasan dan ketidaksempurnaan. Mindfulness melibatkan proses pengamatan dan identifikasi pikiran dan perasaan yang dirasakan, dibanding bereaksi terhadapnya. Atensi mindful merupakan pikiran untuk menolong diri dengan menghayati secara dalam dan belajar untuk keadaan masa kini, tanpa terganggu oleh evaluasi diri atau kekhawatiran masa lalu dan masa depan (Neff, 2003).

Aplikasi self-compassion dalam berbagai psikoterapi telah banyak digunakan dan berimplikasi terhadap kualitas positif individu (Neff \& Knox, 2017). Neff, Kirkpatrick, dan Rude (2007) menjelaskan bahwa selfcompassion memberikan pengaruh yang kuat terhadap penerimaan dan emosi positif terhadap diri. Pengaruh tersebut tidak didasari oleh hasil evaluasi atau perbandingan diri terhadap individu lain, melainkan berfokus pada kesadaran individu terkait sifat manusia yang penuh dengan keterbatasan, sehingga diri mampu mengidentifikasinya dengan jelas dan menyalurkan kebaikan tanpa harus menjatuhkan yang lain.

Costa dan Pinto-Gouveia (2011) menjelaskan bahwa individu dengan penerimaan diri rendah cenderung menghakimi dan mengisolasi diri, serta berlebihan dalam berasumsi. Individu merasakan kesakitan akibat mencoba untuk menghindari dan mengingkari rasa sakit yang dirasakan (Gilbert, 2005). Self-compassion mengajarkan individu untuk tidak menghindari penderitaan, melainkan merangkulnya dengan sikap penuh kasih sayang dan niat tulus, sehingga membentuk rasa kepuasan yang bersumber dari perasaan menjadi manusia sebagaimana harusnya. Konsep tersebut menunjukkan adanya penerimaan tanpa batas dan ambisi untuk mencapai potensi individu sepenuhnya (Barnard \& Curry, 2011).

Self-compassion membantu menghambat rasa sakit dengan memunculkan sikap nonjustifikasi, memperluas persepektif terhadap kehidupan, menerima dengan menyadari berbagai pikiran, perasaan, dan sensasi yang dirasakan tanpa berusaha mengubahnya (Costa \& Pinto-Gouveia, 2011). Self-compassion mampu membuat individu merasa dipedulikan, terhubung, dan tenang secara emosional. Selfcompassion akan menon-aktifkan sistem ancaman yang berkaitan dengan perasaan gelisah, tidak aman, perlawanan, dan sistem limbic, kemudian mengaktifkan sistem penenangan diri yang berkaitan dengan perasaan aman, keterikatan, dan sistem oxytocin-opiate. Hal ini juga dibuktikan oleh Gilbert (2005), yang menggunakan intervensi berbasis compassion terhadap klien yang mengalami perasaan hina dan penyerangan terhadap diri. Intervensi Gilbert berupa Compassion Focused Therapy mampu mengembangkan keterampilan dan atribut pemikiran self-compassion yang bermanfaat untuk menurunkan self-critism yang tinggi (Gilbert, 2005).

Meskipun mampu meningkatkan penerimaan diri secara umum, namun selfcompassion sebagai sikap positif terhadap diri juga bersikap tegas terhadap perilaku yang keliru, agar tidak terjadi self-serving bias. Individu dengan self-compassion merasa peduli terhadap perilaku negatifnya dengan mengubahnya menjadi lebih positif, dibandingkan mengingkarinya (Breines \& Chen, 2012). Hal ini dibuktikan oleh Wang, dkk (2016) yang menemukan bahwa selfcompassion tidak hanya berkontribusi pada kesehatan psikologis individu, tetapi juga mampu mengurangi rasa toleransi terhadap sikap yang melanggar moral. 
Self-compassion juga terbukti mampu meningkatkan motivasi individu untuk meningkatkan kualitas diri, sehingga membentuk integritas diri. Breines dan Chen (2012) dalam penelitian eksperimennya menemukan bahwa self-compassion mampu meningkatkan motivasi individu untuk berubah menjadi lebih baik, bekerja keras, dan memperbaiki serta menghindari kesalahan di masa lalu. Individu dengan self-compassion menargetkan suatu hal secara realistis, sehingga menyadari bahwa terkadang tujuan tidak selamanya dapat tercapai. Self-compassion juga mendukung individu untuk berperilaku hidup sehat (Allen \& Leary, 2014), dan terhindar dari perilaku seks yang berisiko (Rose, dkk, 2014).

Peneliti juga mengambil data terkait tingkat self-compassion para PSK menggunakan skala self-compassion Neff (2003b) dan menemukan bahwa 6 dari 9 responden memiliki tingkat selfcompassion rendah, sedangkan 3 lainnya memiliki tingkat self-compassion sedang. Dengan demikian, pelatihan penerimaan diri yang didasari oleh sikap self-compassion merupakan salah satu alternatif metode yang cukup relevan dengan kondisi kebutuhan para PSK di PPSKW Mattiro Deceng. Hipotesis dalam penelitian ini adalah pelatihan penerimaan diri efektif dalam meningkatkan penerimaan diri PSK. Tingkat penerimaan diri PSK meningkat setelah diberikan pelatihan penerimaan diri.

\section{METODE}

Penelitian ini menggunakan pendekatan kuantitatif eksperimen. Desain ekperimen dalam penelitian ini menggunakan desain quasi experiment dengan pretest and posttest group with follow up. Pengukuran tindak lanjut (follow-up) dilakukan sepekan setelah perlakuan diberikan. Pengukuran dilakukan dengan menggunakan 3 jenis metode, yaitu skala psikologi, wawancara, dan observasi keaktifan subjek selama pelatihan berlangsung yang melibatkan observer.

Penggunaan skala psikologi dalam penelitian ini bertujuan untuk mengukur penerimaan diri subjek. Skala penerimaan diri disusun sendiri oleh peneliti berdasarkan aspek penerimaan diri yang dikemukakan oleh Sheerer (1949), yakni perasaan sederajat, percaya terhadap kemampuan diri, bertanggung jawab, orientasi keluar, berpendirian, menyadari keterbatasan diri, dan menerima sifat kemanusiaan. Skala psikologi yang digunakan hanya diuji secara teoritis yakni dengan analisis keterbacaan oleh subjek sebanyak 2 orang, uji validasi expert judgment, dan uji reliabilitas. Hal ini dikarenakan jumlah kelompok subjek yang terbatas, sehingga peneliti tidak dapat melakukan uji coba terhadap suatu kelompok yang serupa untuk mendapatkan validasi skala secara empirik. Skala psikologi yang digunakan memiliki 42 aitem dengan hasil Aiken's V sebesar 0,75 dan nilai alpha Cronbach sebesar 0,737.

Pelaksanaan wawancara dalam penelitian ini bertujuan untuk mengetahui perubahan perasaan dan pengalaman subjek sebelum dan setelah mengikuti pelatihan. Observasi sebagai teknik pengumpulan data dalam penelitian ini merupakan observasi selama proses pemberian perlakuan berupa pelatihan penerimaan diri dan digunakan sebagai metode untuk mengamati keaktifan subjek. Jenis observasi yang dilakukan dalam penelitian ini adalah observasi rating scale. Penatalaksanaan observasi dilakukan oleh observer yang berjumlah empat orang untung masing-masing subjek. Adapun perilaku spesifik yang diobservasi, yaitu sikap duduk, komunikasi dengan teman, reaksi non verbal (menguap, menangis, tertawa) pada saat mengikuti aktivitas dalam pelatihan penerimaan diri.

Pemberian pelatihan penerimaan diri terdiri dari lima sesi dan dilaksanakan selama dua hari. Pada hari pertama, aktivitas dalam pelatihan penerimaan diri dilakukan secara berkelompok yang meliputi, pemberian materi terkait pengantar self-compassion selama 10 menit, praktik meditasi cermin yang dilakukan selama 20 menit, praktik meditasi kasih sayang yang dilakukan selama 30 menit, dan praktik self talk yang dilakukan selama 20 menit. Pada hari kedua, aktivitas dalam pelatihan dilakukan secara individual yakni setiap subjek dipanggil satu per satu untuk melakukan praktik gestalt two-chair dengan konsep compassion. Sesi gestalt two-chair dengan konsep compassion secara keseluruhan dilakukan selama 3 jam.

Penelitian ini menggunakan teknik pengambilan data purposive sampling. Adapun karakteristik subjek dalam penelitian ini, yaitu PSK yang sedang direhabilitasi di PPSKW Mattiro Deceng, memiliki tingkat penerimaan diri rendah, bersedia dan mampu mengikuti seluruh rangkaian penelitian, mendapatkan izin dari pihak PPSKW Mattiro Deceng. 
Hipotesis pada penelitian ini dianalisis menggunakan teknik analisis data secara deskriptif dan visual inspection, yaitu membandingkan perolehan hasil rata-rata subjek di setiap tahap pengukuran.

\section{HASIL}

Subjek penelitian berjumlah 4 (empat) orang yang memiliki latar belakang lulusan SMP sebanyak 1 orang, dan SD sebanyak 3 orang. Subjek penelitian telah memenuhi karakteristik yang telah ditentukan oleh peneliti. Adapun, deskripsi subjek secara rinci sebagai berikut:

Tabel 1. Deskripsi Kriteria Subjek Penelitian

\begin{tabular}{cccccc}
\hline No & $\begin{array}{c}\text { Inisia } \\
\mathbf{l}\end{array}$ & $\begin{array}{c}\text { Umu } \\
\mathbf{r}\end{array}$ & $\begin{array}{c}\text { Pendidika } \\
\mathbf{n}\end{array}$ & $\begin{array}{c}\text { Nilai } \\
\text { Penjaringa } \\
\mathbf{n}\end{array}$ & $\begin{array}{c}\text { Kategor } \\
\mathbf{i}\end{array}$ \\
\hline . & IW & 45 & SD & 79 & Rendah \\
2. & A & 46 & SMP & 84 & Rendah \\
3. & W & 38 & SD & 83 & Rendah \\
4. & SW & 47 & SD & 81 & Rendah \\
\hline
\end{tabular}

Deskripsi data dalam penelitian ini merupakan hasil kategorisasi variabel berdasarkan mean data hipotetik. Nilai tinggi menunjukkan tingkat penerimaan diri tinggi, sedangkan nilai rendah menunjukkan tingkat penerimaan diri yang juga rendah. Adapun, hasil kategorisasi respon pada skala dapat dilihat pada tabel berikut.

Tabel 2. Kategorisasi Respon Skala Penerimaan Diri

\begin{tabular}{ccccc}
\hline No. & & Frekuensi & Presentase & Kategori \\
\hline 1 & $\mathrm{x} \leq 84$ & 4 & $100 \%$ & Rendah \\
2 & $84 \geq \mathrm{x} \leq 126$ & 0 & 0 & Sedang \\
3 & $126 \leq \mathrm{x}$ & 0 & 0 & Tinggi \\
\hline
\end{tabular}

Data pada tabel 2 menunjukkan bahwa dari empat orang subjek yang mengikuti rangkaian kegiatan intervensi diketahui bahwa semua subjek memiliki tingkat penerimaan diri dalam kategori rendah rendah (100\%).

Keempat subjek yang memiliki kecenderungan penerimaan diri rendah berdasarkan perolehan nilai skala pada pretest tersebut, kemudian diberikan rangkaian intervensi. Setelah subjek mengikuti rangkaian intervensi dilakukan kembali pengukuran posttest dan follow-up. Adapun, data lengkapnya adalah sebagai berikut:
Tabel 3. Hasil Kategorisasi Respon Skala Penerimaan Diri Pre-test, Post-test, dan Follow-up

\begin{tabular}{|c|c|c|c|c|c|c|c|c|c|}
\hline $\begin{array}{l}\mathbf{N} \\
\mathbf{o} \\
.\end{array}$ & $\begin{array}{l}\text { Ini } \\
\text { sial }\end{array}$ & $\begin{array}{c}\text { Pr } \\
\text { e- } \\
\text { tes } \\
t\end{array}$ & $\begin{array}{l}\text { Ka } \\
\text { teg } \\
\text { ori }\end{array}$ & $\begin{array}{l}\text { Po } \\
\text { st- } \\
\text { Te } \\
\text { st }\end{array}$ & $\begin{array}{c}\text { Gai } \\
n \\
\text { sco } \\
\text { re }\end{array}$ & $\begin{array}{l}\text { Ka } \\
\text { teg } \\
\text { ori }\end{array}$ & $\begin{array}{c}\text { Fol } \\
\text { lo } \\
\text { w- } \\
\text { up }\end{array}$ & $\begin{array}{c}\text { Ga } \\
\text { in } \\
\text { sco } \\
\text { re }\end{array}$ & $\begin{array}{l}\text { Kate } \\
\text { gori }\end{array}$ \\
\hline 1 & IW & 79 & $\begin{array}{c}\mathrm{Re} \\
\text { nda } \\
\mathrm{h}\end{array}$ & 96 & 17 & $\begin{array}{c}\mathrm{Se} \\
\text { dan } \\
\mathrm{g}\end{array}$ & $\begin{array}{c}10 \\
0\end{array}$ & 4 & $\begin{array}{c}\text { Sedan } \\
\mathrm{g}\end{array}$ \\
\hline 2 & A & 84 & $\begin{array}{c}\mathrm{Re} \\
\text { nda } \\
\mathrm{h}\end{array}$ & $\begin{array}{c}10 \\
6\end{array}$ & 27 & $\begin{array}{c}\mathrm{Se} \\
\text { dan } \\
\mathrm{g}\end{array}$ & 98 & -8 & $\begin{array}{c}\text { Sedan } \\
\mathrm{g}\end{array}$ \\
\hline 3 & W & 83 & $\begin{array}{c}\mathrm{Re} \\
\text { nda } \\
\mathrm{h}\end{array}$ & $\begin{array}{c}10 \\
0\end{array}$ & 17 & $\begin{array}{c}\mathrm{Se} \\
\text { dan } \\
\mathrm{g}\end{array}$ & $\begin{array}{c}10 \\
2\end{array}$ & 2 & $\begin{array}{c}\text { Sedan } \\
\mathrm{g}\end{array}$ \\
\hline 4 & SW & 81 & $\begin{array}{c}\mathrm{Re} \\
\text { nda } \\
\mathrm{h}\end{array}$ & 92 & 11 & $\begin{array}{c}\text { Se } \\
\text { dan } \\
\mathrm{g}\end{array}$ & $\begin{array}{c}10 \\
9\end{array}$ & 17 & $\begin{array}{c}\text { Sedan } \\
\mathrm{g}\end{array}$ \\
\hline
\end{tabular}

Gambar 1. Diagram Tingkat Penerimaan Diri Subjek pada Skor Total

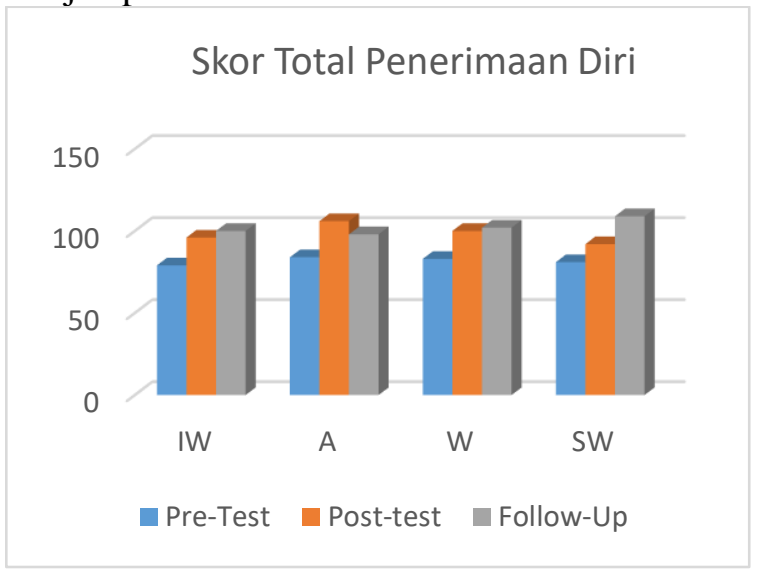

Berdasarkan tampilan tabel 3 dan gambar 1 diatas menunjukkan adanya perubahan nilai yang diperoleh oleh keempat subjek dari pretest, posttest, dan follow-up. Perubahan nilai diatas menunjukkan adanya peningkatan kategori penerimaan diri keempat subjek dari rendah menuju sedang.

Adapun, hipotesis dalam penelitian ini adalah pelatihan penerimaan diri efektif dalam meningkatkan penerimaan diri PSK di PPSKW Mattiro Deceng. Pengujian hipotesis digunakan dengan membandingkan nilai rata-rata keseluruhan subjek yang diperoleh pada pretest, post-test, dan follow-up. Hasil perbandingan nilai rata-rata subjek dapat dilihat pada tabel berikut.

Tabel 4. Hasil Perbandingan Nilai Rata-rata Pengukuran

\begin{tabular}{cccc}
\hline \multirow{2}{*}{ Kelompok } & $\begin{array}{c}\text { Mean } \\
\text { Pre-Test }\end{array}$ & $\begin{array}{c}\text { Mean Post- } \\
\text { Test }\end{array}$ & $\begin{array}{c}\text { Mean Follow- } \\
\text { Up }\end{array}$ \\
\hline Eksperimen & 81,75 & 98,5 & 102,5 \\
\hline
\end{tabular}

Berdasarkan hasil perbandingan nilai ratarata dari hasil pre-test, post-test, dan follow-up, 
dapat dilihat bahwa terjadi peningkatan nilairata dari setiap tahapan pengukuran. Dengan demikian, dapat disimpulkan bahwa pelatihan penerimaan diri efektif dalam meningkatkan penerimaan diri PSK di PPSKW Mattiro Deceng, sehingga hipotesis dalam penelitian ini diterima.

\section{PEMBAHASAN}

Berdasarkan hasil temuan di lapangan melalui wawancara, subjek dalam penelitian ini mengaku menjalankan praktik prostitusi akibat hambatan ekonomi dan konflik keluarga. Ketidakseimbangan antar kebutuhan dan pemasukan berujung pada konflik antar anggota keluarga, yang membuat subjek merasa tidak nyaman. Sehingga, muncul keinginan untuk mendapatkan uang yang lebih banyak melalui cara yang instan. Kartono (2017) mengemukakan bahwa praktik prostitusi dapat dipengaruhi oleh berbagai faktor, beberapa diantaranya yaitu tekanan ekonomi, penghindaran dari kesulitan hidup dan mendapatkan kesenangan melalui jalan pintas, serta latar belakang pendidikan rendah, sehingga sulit mendapatkan pekerjaan yang diinginkan.

Subjek juga menjelaskan bahwa dirinya merasa tidak cocok dengan pekerjaan yang ada di kampung seperti bertani dan bercocok tanam. Subjek ingin memiliki pekerjaan dengan penghasilan yang besar, namun terkendala dengan persaingan pendidikan yang dimiliki orang perkotaan. Di sisi lain, subjek ingin tetap bertahan hidup dan menjalankan gaya hidup seperti orang kota pada umumnya. Kartono (2017) menjelaskan bahwa praktik prostitusi juga bisa disebabkan oleh aspirasi materiil individu yang tinggi terhadap kemewahan, namun malas bekerja.

Dampak yang dirasakan oleh subjek setelah melakukan praktik prostitusi dan terjaring oleh petugas bermacam-macam. Keempat subjek mengaku bahwa dirinya merasa lebih rendah derajatnya dibandingkan orang lain. Subjek mengaku bahwa kondisi pekerjaan dan nasib hidupnya membuatnya merasa lebih rendah dibanding yang lain. Hal ini menyebabkan subjek merasa minder untuk berbaur dengan masyarakat, sehingga memilih bergaul dengan orang yang memiliki pekerjaan yang sama dengannya.

Subjek IW dan A mengaku bahwa dirinya sering termenung dan menangis memikirkan nasib yang dialami dan kondisi keluarganya di kampung. Subjek mengaku merasa tidak nyaman dengan kondisi yang ada di PPSKW Mattiro Deceng. Kurangnya aktivitas yang diberikan membuat subjek sering berpikiran negatif tentang diri dan lingkungan luar, sehingga membuatnya stres.

Ketiga subjek yaitu subjek IW, A, dan SW mengaku bahwa dirinya tidak berani menghubungi keluarganya semenjak terjaring di PPSKW Mattiro Deceng. Hal ini disebabkan dirinya terlalu malu dan takut menghadapi kemarahan keluarga atas perbuatan yang dilakukan. Subjek juga tidak ingin merusak nama keluarga dengan menjadi bahan perbincangan di kampung. Beberapa subjek memilih hanya menghubungi orang-orang tertentu yang sekiranya bisa menerima kondisinya saja.

Dampak yang dirasakan oleh subjek diatas sejalan dengan yang dikemukakan oleh Jajuli (2010) yang menjelaskan bahwa praktik prostitusi menimbulkan dampak psikologis bagi para pelakunya, beberapa diantaranya yaitu merasa harga dirinya rendah di hadapan masyarakat, minder jika berhadapan dengan masyarakat, sering merenung dan menyendiri membayangkan masa lalu, menimbulkan kesenjangan hubungan yang signifikan antara diri dengan keluarga dan masyarakat, kehilangan motivasi untuk menjalin hubungan yang baik dengan masyarakat, stres, frustrasi, hingga depresi.

Hasil respon jawaban subjek penelitian pada pre-test menggunakan skala penerimaan diri diketahui bahwa seluruh subjek (100\%) terindikasi memiliki kecenderungan penerimaan diri rendah. Hasil ini semakin diperkuat dengan hasil wawancara yang dilakukan oleh peneliti terhadap subjek yang menunjukkan adanya karakteristik penerimaan diri rendah, seperti perasaan tidak sederajat dengan orang lain, pesimis terhadap kemampuan diri untuk menjalani hidup yang lebih baik, merasa malu terhadap keadaan diri, ketakutan untuk ditolak oleh orang lain, hingga sikap yang tidak bertanggung jawab terhadap kesalahan yang telah diperbuat.

Penerimaan diri diperlukan bagi para PSK agar mampu menerima dan mengakui kesalahan yang diperbuat, sebagai bagian dari proses pembelajaran hidup sebagai manusia biasa. Sehingga, PSK mampu menganggap dirinya sebagai individu yang setara dengan yang lain, dan mampu beradaptasi, serta 
berfungsi dengan baik di lingkungan masyarakat setelah keluar dari PPSKW Mattiro Deceng. Dengan demikian, intensi untuk kembali melakukan praktik prostitusi semakin menurun.

Kondisi penerimaan diri yang rendah dapat ditingkatkan dengan memberikan pelatihan penerimaan diri. Costa dan Pinto-Gouveia (2011) menjelaskan bahwa individu dengan penerimaan diri rendah cenderung menghakimi diri secara berlebihan, mengisolasi diri dari luar, dan over-identification. Individu cenderung merasakan kesakitan akibat mencoba untuk menghindari dan mengingkari rasa sakit yang dirasakan (Gilbert, 2005). Selfcompassion mengajarkan individu untuk tidak menghindari penderitaan, melainkan merangkulnya dengan sikap penuh kasih sayang dan niat tulus, sehingga membentuk rasa kepuasan yang bersumber dari perasaan menjadi manusia sebagaimana harusnya. Konsep tersebut menunjukkan adanya penerimaan tanpa batas dan ambisi untuk mencapai potensi individu sepenuhnya (Barnard \& Curry, 2011).

Pelatihan penerimaan diri diberikan kepada subjek penelitian secara klasikal dan individual selama dua kali pertemuan. Setelah diberikan pelatihan penerimaan diri, seluruh subjek merasa lebih tenang dan rileks, merasakan emosi yang positif, beban dan pikiran negatif berkurang, hingga berpikir lebih positif. Neff dan Knox (2017) mengemukakan bahwa selfcompassion membantu individu untuk tidak memendam dan merenungkan pikiran dan dorongan negatif. Self-compassion mendatangkan perasaan positif, seperti kebahagiaan, kepuasan hidup, rasa syukur, rasa ingin tahu yang lebih positif, dan kreativitas.

Tentama (2011) mengemukakan bahwa berpikir positif mampu memengaruhi penerimaan diri individu. Berpikir positif mampu membuat individu memusatkan perhatiannya pada hal-hal positif dari suatu permasalahan. Individu yang berpikir positif akan merasa tenang, rileks, mampu menyesuaikan diri, dan memotivasi diri untuk mengatasi permasalahan yang dialami.

Hasil lain yang ditemukan setelah pemberian pelatihan, yaitu subjek mengaku merasa lebih menghargai dan mencintai diri. Subjek IW mengaku kini mampu menilai dirinya lebih positif dari segi fisik. Subjek A menilai dirinya sebagai pribadi yang lebih kuat setelah diberikan pelatihan. Albertson, Neff, dan Dill-Shackleford (2014) mengemukakan bahwa dengan elemen self-kindness pada selfcompassion mampu menurunkan kecenderungan individu untuk mengkritik diri sendiri, dan mengajarkan individu untuk memperlakukan diri dengan lebih lembut. Elemen mindfulness membantu individu untuk melihat tubuh secara lebih jelas dengan keseimbangan yang lebih baik tanpa melebihlebihkan kekurangan yang dimiliki, sehingga individu lebih puas terhadap tubuhnya sendiri.

Subjek A, W, dan SW mengaku bahwa setelah diberikan pelatihan dirinya mampu berpikir secara lebih positif terhadap kehidupan, dan mampu mengambil hikmah dari kejadian di hidupnya. Leary, Tate, Adams, Allen, dan Hancock (2007) menjelaskan bahwa individu dengan self-compassion tinggi ketika dihadapkan pada situasi negatif cenderung tidak mengalami reaksi yang intens, dan emosi negatif yang lebih sedikit. Individu bersikap lebih menerima dan memiliki kecenderungan yang besar untuk memandang masalah dalam perspektif yang lebih luas. Meskipun demikian, individu tetap menyadari tanggung jawabnya secara pribadi.

Hurlock (1980) mengemukakan bahwa individu mendapatkan perspektif yang luas terhadap diri melalui pengalaman dan proses belajar. Perspektif yang lebih luas mampu memengaruhi penerimaan diri individu. Individu lebih membuka diri terhadap pengalaman, tanggapan, dan kritik terhadap dirinya.

Subjek IW yang sebelumnya mengaku takut untuk menghubungi suami dan anak-anaknya, kini telah memberanikan dirinya untuk membuka jalan komunikasi kembali dan meminta maaf atas kesalahannya. Subjek SW yang sebelumnya merasa sakit hati dengan sikap orang yang telah menyakitinya, kini mengaku telah memaafkan orang yang telah menyakiti dirinya.

Yarnell dan Neff (2013) juga menjelaskan bahwa individu dengan self-compassion cenderung menyelesaikan konflik interpersonal dengan yang lain secara lebih damai. Individu menyelesaikan konflik dengan sepenuh hati, sehingga memungkinkan dirinya untuk mengalami intensitas emosi yang lebih rendah. Individu bertindak sesuai dengan pikiran, kata hati, dan nilai-nilai yang dipercaya dalam memelihara hubungannya dengan individu lain.

Subjek A mengaku bahwa setelah diberikan intervensi dan melakukan latihan mandiri 
selama sepekan, terdapat perubahan dalam kualitas tidurnya. Subjek mengaku dapat tidur lebih nyenyak dan bangun dengan badan yang lebih segar. Hu, Wang, Sun, Arteta-Garcia, dan Purol (2016) mengemukakan self-compassion membantu mengurangi stres yang dirasakan individu, sehingga meningkatkan mood dan kesadaran penuh ketika bangun di pagi hari, hingga akhirnya meningkatkan kualitas tidur yang buruk akibat stres.

Subjek IW, A, W lebih termotivasi untuk menjalani hidup dengan lebih baik dan sumber mata pencaharian yang lebih berkah. Hal ini dibuktikan dengan perubahan yang dapat dilihat dari hasil wawancara pre-test dan follow-up. Ketiga subjek menjelaskan rencana yang akan dilakukan setelah keluar dari PPSKW Mattiro Deceng secara lebih jelas dan spesifik pada saat wawancara follow-up, dibandingkan ketika wawancara pre-test.

Breines dan Chen (2012) menjelaskan bahwa self-compassion mampu meningkatkan motivasi individu untuk berubah menjadi lebih baik, bekerja keras, memperbaiki, serta menghindari kesalahan di masa lalu. Selfcompassion mengajarkan individu untuk tidak menghakimi ketika telah melakukan kesalahan, melainkan berusaha untuk memperbaikinya. Individu dengan sikap self-compassion menargetkan suatu hal setinggi mungkin secara realistis, namun juga menyadari bahwa terkadang tujuan tidak selamanya dapat tercapai.

Hurlock (1980) mengemukakan bahwa harapan yang realistis mampu memengaruhi penerimaan diri individu. Individu dengan harapan yang didasari oleh hal nyata dan berdasar pada kemampuan pribadi akan lebih mudah mencapai tujuannya. Harapan yang realistis akan meningkatkan kepuasan individu terhadap dirinya.

Hasil perbandingan nilai rata-rata menunjukkan bahwa terdapat perbedaan penerimaan diri subjek, sebelum, setelah, dan sepekan diberikan pelatihan. Hasil tersebut dapat dilihat dari peningkatan nilai rata-rata subjek keseluruhan pada tahap pre-test, posttest, dan follow-up, yang menunjukkan bahwa pemberian pelatihan penerimaan diri memberikan pengaruh terhadap tingkat penerimaan diri subjek.

Hal ini menunjukkan bahwa pelatihan penerimaan diri memberikan kontribusi terhadap perubahan rata-rata nilai penerimaan diri yang dialami oleh PSK di PPSKW Mattiro
Deceng. Hasil penelitian ini sejalan dengan penelitian yang dilakukan oleh Gilbert (2005) dengan menggunakan intervensi self compassion berupa Compassion Focused Therapy (CFT), yang diberikan kepada klien dengan self-critism yang tinggi. Hasil dari penelitian tersebut menunjukkan bahwa CFT efektif untuk mengembangkan keterampilan dan atribut pemikiran self-compassion, terutama ketika klien mengalami perasaan hina dan penyerangan terhadap diri. Penelitian ini juga mendukung hasil dari penelitian yang dilakukan oleh Albertson, Neff, dan DillShackleford (2014) yang mampu menurunkan kecenderungan subjek untuk mengkritik diri sendiri melalui pelatihan self-compassion, sehingga meningkatkan body disatisfaction subjek dengan body image yang lebih positif.

Adapun kelemahan dalam penelitian adalah penyampaian materi yang kurang menarik dan belum sesuai dengan kondisi subjek. Meskipun pemberian pelatihan telah diselingi beberapa icebreaking, berdasarkan hasil observasi masih terdapat beberapa perilaku subjek yang menunjukkan sikap tidak siap ketika menerima materi. Hal ini mungkin saja disebabkan oleh pembawaan materi yang terkesan serius, dan penggunaan bahasa dalam materi pelatihan yang terlalu kompleks untuk subjek. Selain itu, durasi waktu yang digunakan untuk pemberian intervensi hanya dua kali pertemuan, dan latihan mandiri yang dilakukan setiap subjek hanya seminggu, sehingga hasil yang diperoleh kurang maksimal. Meskipun tingkat penerimaan diri keempat subjek mengalami peningkatan, hasil dari keempat subjek hanya meningkat pada kategori sedang saja. Hasil peningkatan penerimaan diri subjek mungkin saja akan lebih baik jika subjek melakukan praktik latihan mandiri dengan periode waktu yang lebih lama dari sepekan. Penggunaan alat ukur skala penerimaan diri dalam penelitian ini juga kurang maksimal karena populasi subjek yang sedikit, sehingga peneliti hanya melakukan uji validitas secara logis dan tidak melakukan uji validitas secara empirik.

\section{KESIMPULAN}

Berdasarkan hasil yang diperoleh dapat disimpulkan bahwa pelatihan penerimaan diri efektif untuk meningkatkan penerimaan diri Pekerja Seks Komersial (PSK) di PPSKW Mattiro Deceng. Terdapat peningkatan tingkat penerimaan diri PSK sebelum mendapatkan 
pelatihan penerimaan diri (pre-test) dan setelah mendapatkan pelatihan penerimaan diri (posttest). Adapun rekomendasi yang dapat diajukan oleh peneliti untuk peneliti selanjutnya yaitu, agar lebih memperhatikan penatalaksanaan intervensi. Alangkah baiknya jika pemberian intervensi disesuaikan dengan kondisi subjek dengan menggunakan bahasa yang lebih sederhana, pembawaan materi yang santai dan terkesan tidak menggurui, serta icebreaking yang menarik. Peneliti juga merekomendasikan saran kepada pihak PPSKW Mattiro Deceng, agar memberikan kegiatan yang lebih bervariatif bagi para penerima manfaat, sehingga para penerima manfaat tidak menghabiskan waktunya untuk merenung. Praktik self-compassion yang diajarkan dapat dijadikan sebagai alternatif sebagai kegiatan yang dapat dilakukan secara kelompok maupun individual untuk meningkatkan emosi dan mood yang lebih positif bagi para penerima manfaat maupun pekerja social yang ada di PPSKW Mattiro Deceng.

\section{DAFTAR PUSTAKA}

Ackerman, C. (2018). What is self-acceptance? 25 exercises + definition and quotes, diakses dari https://positivepsychology.com/selfacceptance/, pada tanggal 18 Februari 2020.

Allen, A. B., \& Leary, M. R. (2014). Selfcompassionate responses to aging. The Gerontologist, 54(2), 190-200.

Albertson, E. R., Neff, K. D., \& DillShackleford, K. E. (2014). Self-compassion and body dissatisfaction in woman: A randomized controlled trial of a brief meditation intervention. Mindfulness, 6, 111.

Angeline, S., \& Ronda, D. (2011). Pemulihan gambar diri bagi para pekerja seks komersial di pusat pelayanan satuan karya wanita Mattiro Deceng Makassar. Jurnal Jaffray, 9(2), 31-52.

Barnard, L. K., \& Curry, J. F. (2011). Selfcompassion: Conceptualization, correlates, \& interventions. Review of general psychology, 15(4), 289-303.

Breines, J. G., \& Chen, S. (2012). Selfcompassion increases self-improvement motivation. Personality and Social Psychology Bulletin, 38(9), 1133-1143.

Costa, J., \& Pinto-Gouveia, J. (2011). Acceptance of pain, self-compassion and psychopathology: Using the chronic pain acceptance quistonnaire to identify patients' subgroups. Clinical Psychology \& Psychotherapy, 18(4), 292-302.

Gilbert, P. (2005). Compassion: Conceptualization, research, and use in psychotherapy. London: Routledge.

Hu, Y., Wang, Y., Sun, Y., Arteta-Garcia, J., \& Purol, S. (2018). Diary study: The protective role of self-compassion on stress-related poor sleep quality. Mindfulness, 9(6), 19311940.

Hurlock, E. B. (1980). Psikologi perkembangan suatu pendekatan sepanjang rentan kehidupan. Terjemahan oleh Istiwidayanti dan Soedjarwo. Jakarta: Erlangga.

Jajuli. (2010). Motivasi dan dampak psikologis pekerja seks komersial (Studi kasus terhadap PSK di Gunung Kemukus Sragen Jateng). Skripsi. Fakultas Dakwah: Universitas Islam Negeri Sunan Kalijaga Yogyakarta.

Kartono, K. (2017). Patologi sosial jilid 1. Jakarta: Rajawali Pres.

Kirkpatrick, K. L. (2005). Enhancing selfcompassion using a Gestalt two-chair intervention. (Disertasi). Austin: University of Texas.

Leary, M. R., Tate, E. B., Adams, C. E., Allen, A. B., \& Hancock, J. (2007). Selfcompassion and reactions to unpleasant selfrelevant events: The implications of treating onself kindly. Journal of Personality and Social Psychology, 92(5), 887-904.

Neff, K. D. (2003a). Self-compassion: An alternative conceptualization of a healthy attitude toward oneself. Self and Identity, 2(2), 85-101.

Neff, K. D. (2003b). The development and validation of a scale to measures selfcompassion. Self and identity, 2(3), 223250.

Neff, K. D., Kirkpatrick, K. L., \& Rude, S. S. (2007). Self-compassion and adaptive psychological functioning. Journal of Research in Personality, 41(1), 139-154.

Neff, K. D., \& Knox, M. C. (2017). Selfcompassion.In V. Zeigler-Hill, T. K Shackelford (Eds.), Encyclopedia of Personality and Individual Differences, pp.1-8. New York: Springer International Publishing.

Permatasari, V., \& Gamayanti, W. (2016). Gambaran penerimaan diri (self-acceptance) pada orang yang mengalami 
skizofrenia. Psympathic: Jurnal Ilmiah Psikologi, 3(1), 139-152.

Rose, C. D., Webel, A., Sullivan, K. M., Cuca, Y. P., Wantland, D., Johnson, M. O., Chen, W. T., Phillips, J. C., Tyder-Viola, L., Rivero-Mendez, M., Nicholas, P. K., Nokes, K., Kemppainnen, J., Sefcik, E., Eller, L.C., Lipinge, S., Kirskey, K., Chaiphibalsarisdi, P., Davila, N., Hamilton, M. J., Hickey, D., Maryland, M., Reid, P., \& Holzemer, W. L (2014). Self-compassion and risk behaviour among people living with HIV/AIDS. Research in Nursing \& Health, 37(2), 98106.

Sahyana. (2017). Proses rehabilitasi wanita pekerja seks komersial (PSK) dalam pembentukan konsep diri di Pusat Pelayanan Sosial Karya Wanita Mattiro Deceng Sudiang Makassar. (Skripsi diterbitkan). Makassar: Universitas Islam Alauddin Makasssar.

Sari, E. P., \& Nuryoto, S. (2002). Penerimaan diri pada lanjut usia ditinjau dari kematangan emosi. Jurnal Psikologi, 29(2), 73-88.

Sheerer, E. T. (1949). An analysis of the relationship between acceptance of and respect for self and acceptance of and respect for others in ten counselling cases. Journal of Consulting Psychology, 13(3), 169-175.

Tentama, F. (2011). Hubungan antara berpikir positif dengan penerimaan diri pada remaja penyandang cacat tubuh akibat kecelakaan. Prosiding Seminar Nasional Hasil Pendidikan Dosen Kopertis Wilayah V Yogyakarta.

Wang, X., Chen, Z., Poon, K. T., Teng, F., \& Jin, S. (2017). Self-compassion decreases acceptance of own immoral behaviors. Personality and Individual Differences, 106, 329-333.

Yarnell, L. M., \& Neff, K. D. (2013). Selfcompassion, interpersonal conflict resolutions, and well-being. Self and Identity, 12(2), 146-159. 